\title{
Benzo[c]phenanthrene derivatives: Synthesis, optical properties and cytotoxic activity
}

\author{
HabibaGuédouar, FaouziAloui and Béchir Ben Hassine* \\ Laboratoire de Synthèse Organique Asymétrique et Catalyse Homogène (11URES56), Faculté des Sciences \\ de Monastir, Université de Monastir, Bd., de l'Environnement, 5019 Monastir, Tunisia *Correspondence to B. \\ Ben Hasssine Tel.: +216 73500 279; Fax: +216 73500 278. E-mail address: bechirbenhassine@yahoo.fr \\ bechirbenhassine@yahoo.fr
}

\section{ABSTRACT}

A new benzo[c]phenanthrene ketone has been synthesized through Heck coupling and oxidative photocyclization. The optical properties of the targettetracyclic system were also investigatedby UV-visible absorption and photoluminescence spectroscopy and an emission in the visible region was observed. The tetracyclic ketone has been reacted with primary amines in the presence of Lewis acid followed by $\mathrm{NaBH}_{4}$ reduction to provide new polyaromatic secondary aminesin good yields and purity. All the synthesized new compounds were identified and characterized through a combination of nuclear magnetic resonance spectroscopy and mass spectrometric methods. The cytotoxic activity of all pure benzo[c]phenanthrene derivatives has been evaluated against Hep-2cell line using (MTT) colorimetric assay.

\section{Keywords}

Benzo[c]phenanthrene, Ketone, Heck coupling, Photocyclization,Amines, Cytotoxic activity.

\section{Academic Discipline And Sub-Disciplines}

Chemistry

\section{SUBJECT CLASSIFICATION}

Organic Synthesis

\section{TYPE (METHOD/APPROACH)}

Benzo[c]phenanthrene derivatives

\section{INTRODUCTION}

Small polyaromatic molecules are of large importance due to their rich chemistry,[1] physical properties,[2,3]technological and industrial applications.[1]The benzo[c]phenanthreneskeletonis a versatile key building block toward many large functionalized polycyclic aromatic hydrocarbons as well as helicenes.[4-8]The synthesis of the benzo[c]phenanthrene derivatives is of great importance in organic chemistry. Indeed, the construction of an arylheteroatom bond is an important study; in particular, the formations of the carbon-oxygen bonds have received vast attention due to the occurrence of these bonds in many molecules such as 1-3 (Fig. 1) which are of biological interests.[912]

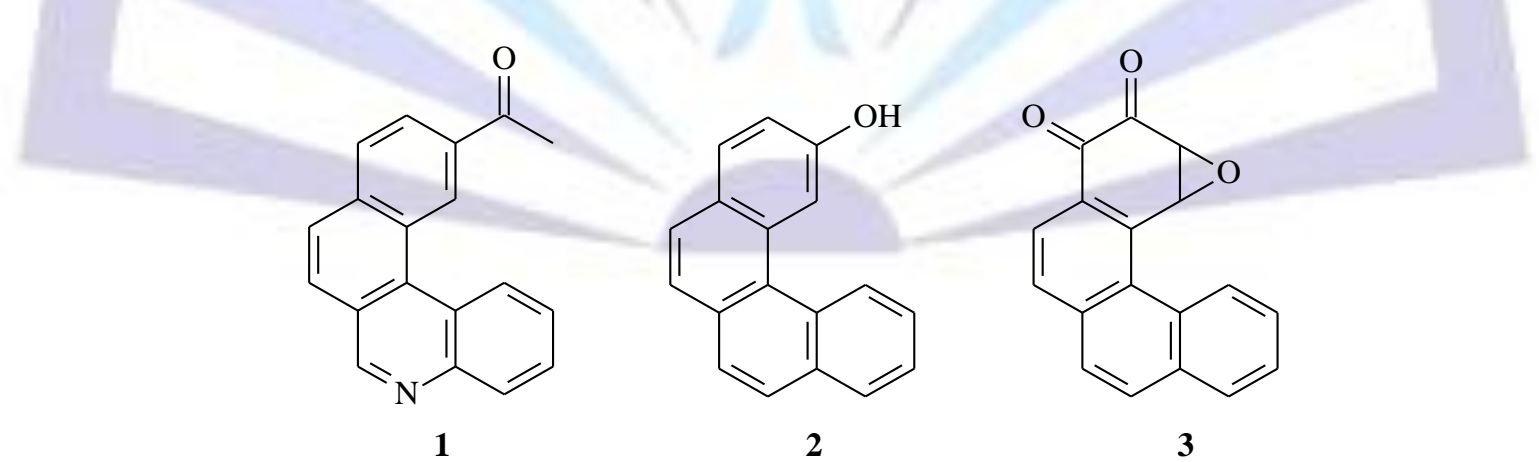

Figure 1-Representative examples of benzo[c]phenanthrene derivatives.

For example, the ketones constitute a class of compounds that have various and important applications in diastereoselective organic synthesis.[13]Ketones can interact highly with amines in acidic medium due to the presence of labile hydrogen in these molecules which leads to the synthesis of imines. Thus the formation of carbon-nitrogen double bond plays high role in asymmetric synthesis. The classical method for synthesis of imines was reported by Schiff[14] which implicates condensation of primary amines with carbonyl compounds under azeotropic distillation.[15] The use of a Lewis acid accelerates the nucleophilic attack of the carbonyl carbon by amines leading to prochiral imines.

Secondary amines form a category of compounds that find different and important applications in modern synthetic chemistry. They are used as chiral derivatizing agents,[16-21] ligands[22-25] and chiral auxiliaries in asymmetric 
synthesis.[26-28] Useful syntheticapproaches have been reportedto produce chiralamines, and many transformations have been developed, such astheaddition of Grignard reagents,[29] direct C-H amination,[30] Mannich reaction[31-33] and hydrogenation of iminiums.[34-36]

In this paper, we describe a convenient procedure for the synthesis of a new benzo[c]phenanthrene ketone witch has been used as a suitable key building block to provide new secondary amines. All obtained pure benzo[c]phenanthrene derivatives have been evaluated as cytotoxic agents against Hep-2cell line. The optical properties of thetetracyclic ketone have been also investigatedby UV-visible absorption spectroscopy and show an interesting behaviour.

\section{RESULTS AND DISCUSSION}

\section{Oxidative photolysis}

The synthesis of the chiral amines was performed as shown in schemes 1-3.p-bromoacetophenone4 undergo Heck coupling with 2-vinylnaphtalene $\mathbf{5}(1.5$ equiv.) in the presence of Hermann's catalyst $(1 \mathrm{~mol} \%)$ and sodium acetate in DMA, to produce alkene 6 in $73 \%$ yield (Scheme 1). The latter was subjected to photocyclization using a $500 \mathrm{~W} \mathrm{Hg}$-vapor lamp, on a $500 \mathrm{mg}$ scale per 1 liter of toluene in the presence of a stoechiometric amount of iodine as an oxidizing agent and excess of propylene oxide as a hydrogen iodide scavenger, to afford the 2-acetylbenzo[c]phenanthrene7in $84 \%$ yield, after purification by column chromatography.

Chemical shifts for $\mathrm{H}-1$ and $\mathrm{H}-12$ are characteristic of the benzo[c]phenanthrene pattern. Careful analysis of ${ }^{1} \mathrm{H}$ NMR spectra evidenced the presence of a singlet resonating at 9.75 and a doublet at $9.06 \mathrm{ppm}(J=8.1 \mathrm{~Hz})$ that account for protons $\mathrm{H}-1$ and $\mathrm{H}-12$, respectively.

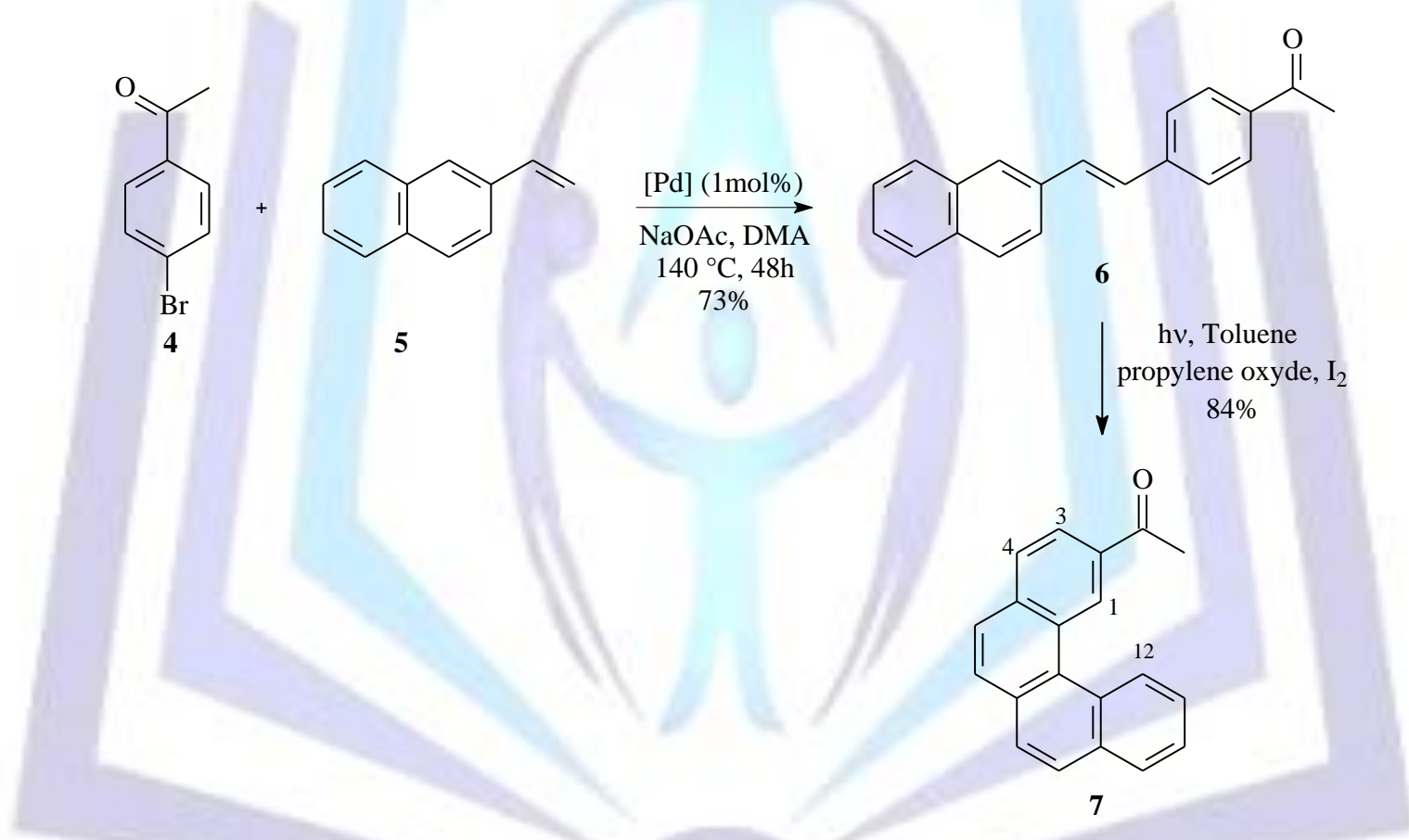

Scheme 1-Synthetic procedure of the tetracyclic ring system 7.

\section{Optical Properties}

The optical properties of the diarylethene6 and 2-acetylbenzo[c]phenanthrene7 were investigated using UV/vis absorption studies in dilute $\left(1.5 \times 10^{-6} \mathrm{M}\right)$ dichloromethane solutions (Fig. 2). The UV/vis spectra of these compounds exhibited a strong absorption in the region of $250-400 \mathrm{~nm}$. The absorption in the high energy region is well structured containing four prominent bands at 282, 291, 340 and $367 \mathrm{~nm}$ for diarylethene6, and five prominent bands at 289, 326, 341,371 and $389 \mathrm{~nm}$ for the tetracyclic system 7. These absorption bands are associated with $\pi-\pi^{*}$ and $n-\pi^{*}$ electronic transitions. No broad absorption band in the low energy region was observed. The optical band gaps (Eg) determined from the absorption edge of the solution spectra are given in Table 1. 

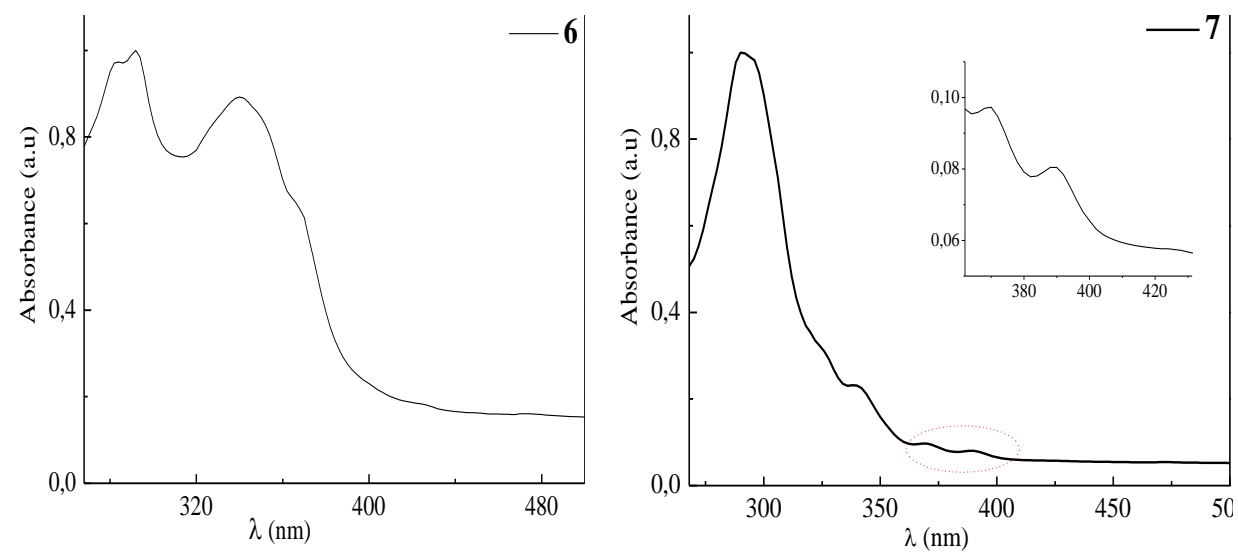

Figure2- Normalized UV/vis absorption spectra of diarylethene 6 and the tetracyclic system 7 in dilute dichloromethane solutions $\left(1.5 \times 10^{-6} \mathrm{M}\right)$.

\section{Table1}

Physical properties of diarylethene6 and the corresponding tetracyclic ketone 7.

\begin{tabular}{lllll}
\multirow{2}{*}{ Compound } & \multicolumn{2}{c}{ Absorption } & \multicolumn{2}{c}{ Photoluminescence } \\
\cline { 2 - 5 } & $\lambda_{\max }^{a b s}(\mathrm{~nm})^{a}$ & $\mathrm{Eg}(\mathrm{eV})^{b}$ & $\lambda \mathrm{ems}(\mathrm{nm})^{c}$ & ${\mathrm{FWHM}(\mathrm{nm})^{d}}^{c}$ \\
6 & 292 & 3.11 & 501 & 44 \\
7 & 291 & 3.05 & 441 & 45
\end{tabular}

${ }^{a}$ Absorption maxima, measured in $\mathrm{CH}_{2} \mathrm{Cl}_{2}$ solutions $\left(1.5 \times 10^{-6} \mathrm{M}\right)$ at rt.

${ }^{b}$ The optical gap $\left(E_{g-o p}\right)$ was estimated from the onset point of the absorption spectra: $E_{g-o p}=1240 / \lambda_{\text {onset }}$.

${ }^{c}$ Emission maxima, measured in thin solid film at rt.

${ }^{d}$ Spectrum full width at half maximum.

The photoluminescent properties of compounds 6 and 7 were investigated at room temperature and the obtained spectra were illustrated in Figure 3. Diarylethene6exhibit a green emission with a structured PL spectrum bearing a maximum at $501 \mathrm{~nm}$ and five shoulder peaks at 459, 480, 516, 538 and $613 \mathrm{~nm}$. Indeed, the film spectrum can be Gaussian-divided into six subbands (peaked near 420, 448, 481, 509, 531 and $619 \mathrm{~nm}$ ) as shown in Figure 4a.

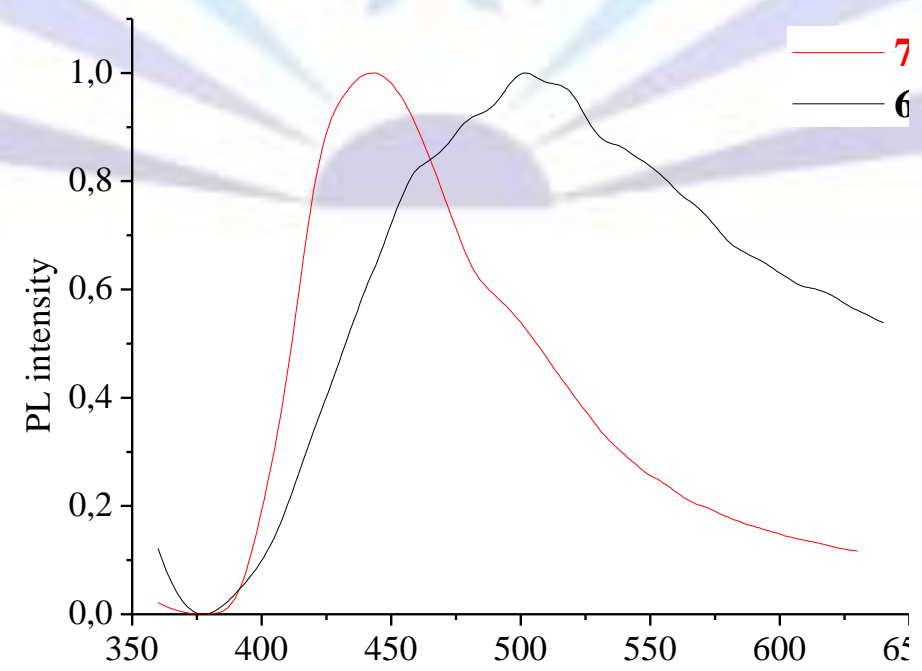

Figure 3- Normalized emission of compounds 6 and 7 inthin solid film. 
While, the tetracyclic system 7 showed a blue emission with a structured PL spectrum bearing a maxima at $441 \mathrm{~nm}$, and a shoulder peak at $493 \mathrm{~nm}$. As shown in Figure 4b, two subbands in the film spectrum (440 and $497 \mathrm{~nm}$ ) were observed.
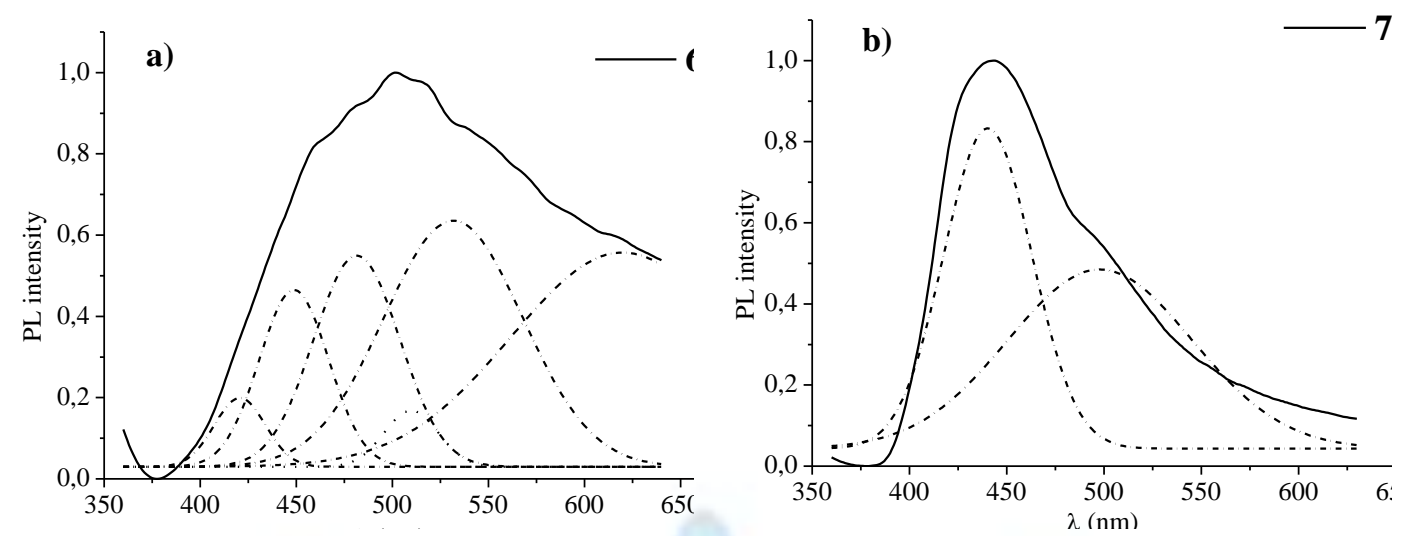

Figure 4-a) Gaussian fits for diarylethene6; b) Gaussian fits for 2-acetylbenzo[c]-phenanthrene7.

\section{Synthesis of the secondary amines}

The resulting benzo[c]phenanthreneketone 7 was reacted first with aniline 8in refluxing toluene, using a Dean-Stark apparatusin the presence of $p$-toluenesulfonic acid (Scheme 2).[37-40]Indeed, the yield did not exceed $20 \%$ and this after a reaction time of three days. The use of a Lewis acid appears to be critical for the success of the reaction and for this reason anhydrous $\mathrm{ZnCl}_{2}(10 \mathrm{~mol} \%)[41,42]$ has been used as a catalyst during eight hours to give the desired imine 9 which has been then used without purification because of its low stability.

The most common method for the synthesis of chiral amines belongs to the hydrogenation of prochiral imines.For this, we proceeded to the reductive amination[43-45] as a direct method for the synthesis of amines. We used sodium borohydride as a reducing agent, because it is inexpensive, safe to handle and an environmental friendly reagent. Thus, imine 9 wasreduced with $\mathrm{NaBH}_{4}$ in methanol to give racemic amine 10 in $68 \%$ yield.<smiles>CC(=O)c1ccc2ccc3ccc4ccccc4c3c2c1</smiles>

7<smiles>Nc1ccccc1</smiles>

8

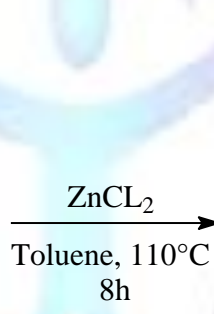<smiles>CC(=Nc1ccccc1)c1ccc2ccc3ccc4ccccc4c3c2c1</smiles>
$\mathrm{MeOH}, 2 \mathrm{~h}$ $\checkmark 68 \%$<smiles>CC(Nc1ccccc1)c1ccc2ccc3ccc4ccccc4c3c2c1</smiles>

10

\section{Scheme 2-Synthesis of the new racemic secondary amine 10.}

In order to prepare optically active amines, we carried out the condensation the tetracyclic system 7with $(R)-(+)-\alpha-$ methylbenzylamine11in refluxing toluene, using a Dean-Stark apparatus, in the presence of $\mathrm{ZnCl}_{2}(10 \mathrm{~mol} \%)$ which provided the expected imine12 (Scheme 3). Reduction of the latter using the same conditions as for imine 9 allowed the formation of optically active amines $13 \mathbf{a}, \mathbf{b}$ in $90 \%$ yield. 
<smiles></smiles><smiles>C[C@H](N)c1ccccc1</smiles>

$8 \mathrm{~h}$

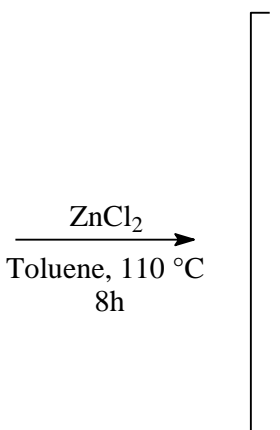<smiles>CC(=N[C@@H](C)c1ccccc1)c1ccc2ccc3ccc4ccccc4c3c2c1</smiles>

12

$\mathrm{NaBH}_{4}$

$\mathrm{MeOH}, 2 \mathrm{~h}$

$\checkmark 90 \%$

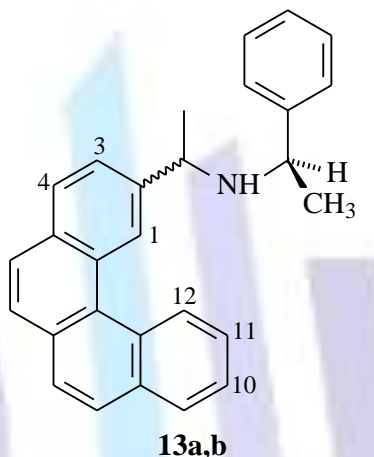

(mixture of diastereomers)

Scheme 3-Synthetic pathway for the synthesis of the optically active amines $\mathbf{1 3 a} \mathbf{a} \mathbf{b}$.

We also managed to separate the two diastereomeric amines $13 \mathbf{a}$ and $\mathbf{1 3 b}$ by chromatography on a silica gel column with cyclohexane-EtOAc (98:02 up to 80:20) aseluent. The fractions eluted were checked by TLC. The earlier eluting fractions consisted of the diastereomer $13 \mathrm{a}\left(R_{\mathrm{f}}=0.25\right)$, which was obtained in $72 \%$ yield.Later eluting fractions gave the second diastereomer13b $\left(R_{\mathrm{f}}=0.23\right)$ in $18 \%$ yield.

\section{Cytotoxic Activity}

The 3-(4,5-dimethylthiazol-2-yl)-2,5-diphenyltetrazolium bromide (MTT) colorimetric assay[46,47]was used to screen the cytotoxic activity of the benzo[c]phenanthrene derivatives.[48-51] Results were generated from three independent experiments and each experiment was performed in triplicate. Percent cytotoxicity was calculated by using the following equation:

$$
\% \text { cytotoxicity }=100-[(\text { absorbance of treated sample) } / \text { (control absorbance) }] \text { x100 }
$$

The stock solutions $(5 \mathrm{mg} / \mathrm{mL})$ of pure compounds were prepared in dimethylsulfoxide (DMSO) and the final concentration of this solvent was kept constant at $0.25 \%$. The serial dilutions with the culture media were prepared just prior to addition to test (Table 2). The cytotoxic activity of the benzo[c]phenanthrene derivativesagainst Hep-2 cells which have been treated with test compound at various concentrations $(10,5,2.5,1.25 \mu \mathrm{g} / \mathrm{mL})$, are listed in table 2 .All compounds seem to be a potent cytotoxic agent at the highest concentration $(10 \mu \mathrm{g} / \mathrm{mL})$.

\section{Table 2}

Cytotoxic activity of the benzo[c]phenanthrenederivatives.

\begin{tabular}{lcccc}
\hline \multirow{2}{*}{ Compound } & \multicolumn{4}{c}{ Concentrations $(\mu \mathrm{g} / \mathrm{mL})$} \\
\cline { 2 - 5 } $\mathbf{7}$ & 10 & 5 & 2.5 & 1.25 \\
\cline { 2 - 5 } $\mathbf{1 0}$ & $47.27 \pm 3.58$ & $30.05 \pm 1.24$ & $25.88 \pm 2.71$ & $11.01 \pm 0.9$ \\
$\mathbf{1 3 a}$ & $67.44 \pm 3.06$ & $47.47 \pm 2.03$ & $37.01 \pm 2.09$ & $17.01 \pm 2.09$ \\
$\mathbf{1 3 b}$ & $78.69 \pm 1.91$ & $55.35 \pm 2.55$ & $45.03 \pm 2.07$ & $36.44 \pm 2.06$ \\
& $92.08 \pm 2.02$ & $83.75 \pm 0.25$ & $72.80 \pm 2.32$ & $70.02 \pm 2.08$ \\
\hline
\end{tabular}


As shown in figure 3 , it was evident from the data that change of substituents on the benzo[c]phenanthrene derivativeshad a significant influence on the cytotoxicity. We also noted that adding an amine function to the benzo[c]phenanthrene moiety increases this activity. Therefore, the secondary amines 10, 13a and 13b showed higher activity compared to benzo[c]phenanthrene ketone 7.

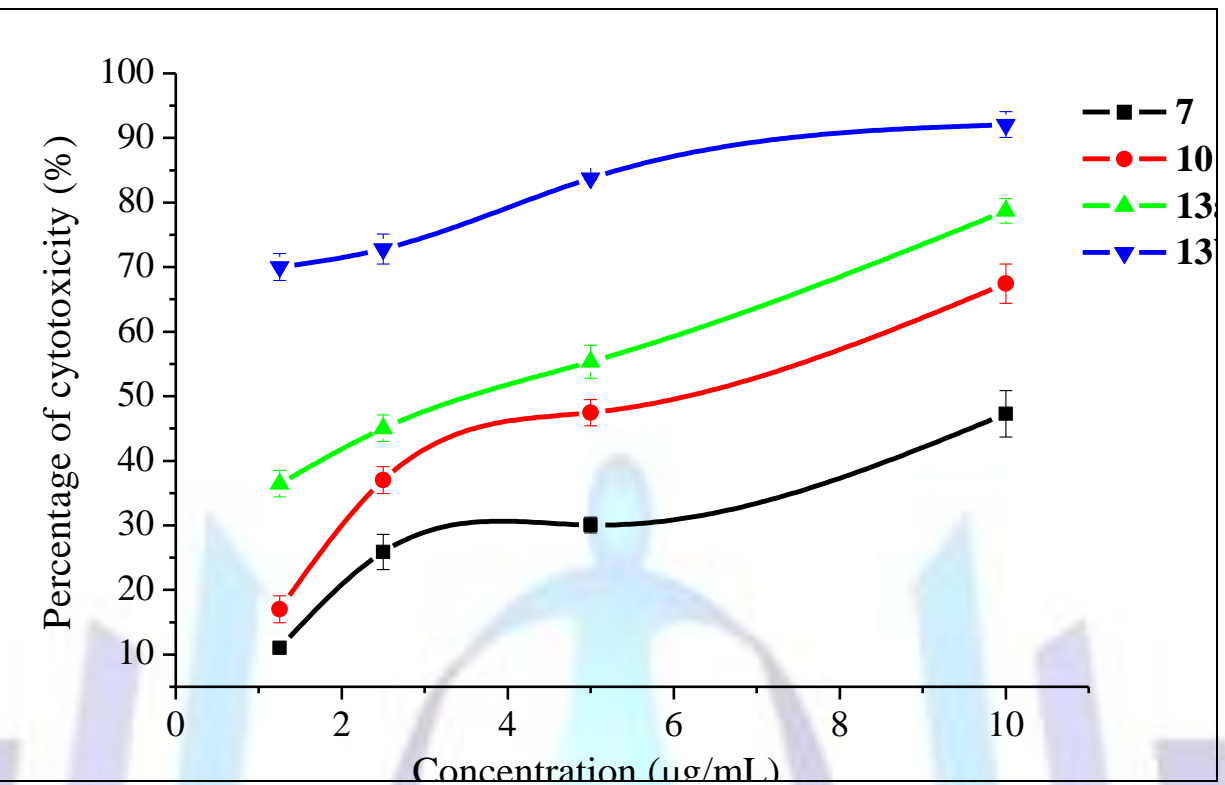

Figure 3-Cytotoxic activity of benzo[c]phenanthrene derivatives against $\mathrm{Hep-2}$ cell line

(Values were expressed as means \pm standard deviation of three experiments).

\section{Experimental section}

All reactions were performed under an argon atmosphere and were monitored by thin-layer chromatography (TLC) Merck 60 F-254 silica-gel plates (layer thickness $0.25 \mathrm{~mm}$ ). Column chromatography was performed on silica gel (70-230 mesh) using cyclohexane and ethyl acetate mixture as eluents. Melting points were determined on an Electrothermal 9002 apparatus and were reported uncorrected. NMR spectra were recorded on a Bruker AC-300 spectrometer $\left[300 \mathrm{MHz}\left({ }^{1} \mathrm{H}\right)\right.$ and $\left.75 \mathrm{MHz}\left({ }^{13} \mathrm{C}\right)\right]$. All chemical shifts were reported as $\delta$ values $(\mathrm{ppm})$ relative to internal tetramethylsilane. Toluene and methanol were distilled prior to use. Photocyclizationswere carried out in a 1.5-L water-cooled quartz photoreactor equipped witha high-pressure mercury immersion lamp [Heraeus TQ 500]. Time-of-flight mass spectroscopy (TOF MS $\mathrm{ES}^{+}$) was carried out on a Micromass, UK and Manchester. Detection was performed at $254 \mathrm{~nm}$ and $365 \mathrm{~nm}$.

\section{Cell lines and culture medium}

Theepidermoid carcinoma epithelial cell (Hep-2; ATCC CCL-23)was cultured in Dulbecco's modified Eagle medium (DMEM) supplemented with $10 \%$ fetal bovine serum, $1 \%$ non-essential amino acids and $1 \%$ penicillin/streptomycin (Invitrogen). At $85-90 \%$ confluence, cell was harvested using $0.25 \%$ trypsin/EDTA solution and sub-cultured onto $96-$-well plates according to the experimental requirements.

\section{Cytotoxicity screening assay}

Briefly, the Hep-2 cell line $\left(1 \times 10^{5}\right.$ cell/well) was grown overnight on 96 -well flat bottom cell culture plates, incubated $24 \mathrm{~h}$. When a partial monolayer had formed, the supernatant was flicked off, the monolayer washed once with medium and $100 \mu \mathrm{L}$ of different concentrations $(10,5,2.5$ and $1.25 \mu \mathrm{g} / \mathrm{mL})$ of pure benzo[c]phenanthrene derivatives were added to the cell in the microtitre plates. After $24 \mathrm{~h}$, the cell were washed and treated with $0.01 \mathrm{~mL}$ MTT reagent (Invtrogen) prepared in $5.0 \mathrm{mg} / \mathrm{mL}$ phosphate buffered saline (PBS) per well. Plates were incubated at $37{ }^{\circ} \mathrm{C}$ in a $5 \% \mathrm{CO}_{2}$ atmosphere for $4 \mathrm{~h}$, and $0.1 \mathrm{~mL}$ dimethylsulfoxide (DMSO) was added. After an overnight incubation at $37^{\circ} \mathrm{C}$, the absorbance was measured at $550 \mathrm{~nm}$ using an ELISA reader (Thermo scientific Multiskan FC) and was compared with the control cultures without compounds.

\section{(E)-1-(p-(2-naphth-2-yl)vinylphenylethanone(6)}

A solution of $p$-bromoacetophenone4 $(0.5 \mathrm{~g}, 2.51 \mathrm{mmol})$ and dry $\mathrm{NaOAc}(226 \mathrm{mg}, 2.76 \mathrm{mmol})$ in $\mathrm{N}, \mathrm{N}$ dimethylacetamide $(3 \mathrm{~mL})$ was placed in a Schlenk tube and repeatedly degassed and purged with argon fivetimes. 2vinylnaphtalene $5(0.55 \mathrm{~g}, 3.57 \mathrm{mmol})$ was added and the mixture was heated to $100{ }^{\circ} \mathrm{C}$. Next, a solution of Herrmann's catalyst (23 mg, $1 \mathrm{~mol} \%$ ) in $\mathrm{N}, \mathrm{N}$-dimethylacetamide $(2 \mathrm{~mL})$ was added and the mixture was heated to $140{ }^{\circ} \mathrm{C}$. Heating wasmaintained for about $48 \mathrm{~h}$. The product was worked up by addition of $\mathrm{H}_{2} \mathrm{O}$ and extractionof the organic phase with EtOAc $(3 \times 30 \mathrm{~mL})$. The combined organic phases were driedover $\mathrm{MgSO}_{4}$. After removal of the solvent, the residue was purified by a silica gel columnchromatography with cyclohexane/EtOAc $(98 / 02)$ as the eluent. $73 \%$ yield; yellow solid; $R_{\mathrm{f}}=$ $0.22 ; \mathrm{mp}=164-166^{\circ} \mathrm{C} ;{ }^{1} \mathrm{H}$ NMR $\left(300 \mathrm{MHz}, \mathrm{CDCl}_{3}\right): \delta(\mathrm{ppm}): 2.60\left(\mathrm{~s}, 3 \mathrm{H}, \mathrm{CH}_{3}\right), 7.24\left(\mathrm{~d}, J=15 \mathrm{~Hz}, 1 \mathrm{H}, \mathrm{H}_{\text {vinyl) }}\right), 7.38(\mathrm{~d}, J=$ 
$\left.18 \mathrm{~Hz}, 1 \mathrm{H}, \mathrm{H}_{\text {vinyl }}\right), 7.44-7.51(\mathrm{~m}, 2 \mathrm{H}), 7.62(\mathrm{~d}, J=9 \mathrm{~Hz}, 2 \mathrm{H}), 7.73\left(\mathrm{dd}, J_{1}=9 \mathrm{~Hz}, J_{2}=3 \mathrm{~Hz}, 1 \mathrm{H}\right), 7.80-7.88(\mathrm{~m}, 4 \mathrm{H}), 7.96(\mathrm{~d}$, $J=6 \mathrm{~Hz}, 2 \mathrm{H}) ;{ }^{13} \mathbf{C} \mathbf{R M N}\left(75 \mathrm{MHz}, \mathrm{CDCl}_{3}\right): \delta(\mathrm{ppm}): 26.05\left(\mathrm{CH}_{3}\right), 122.92(\mathrm{CH}), 125.80(\mathrm{CH}), 126.02(2 \mathrm{CH}), 126.88(\mathrm{CH})$, $127.25(\mathrm{CH}), 127.27(\mathrm{CH}), 127.63(\mathrm{CH}), 127.99(\mathrm{CH}), 128.41(2 \mathrm{CH}), 131.07(2 \mathrm{CH}), 132.86(\mathrm{C}), 133.15(\mathrm{C}), 133.73(\mathrm{C})$, $135.53(\mathrm{C}), 141.56(\mathrm{C}), 196.92(\mathrm{CO})$; IR: $\left(\mathrm{V}_{\mathrm{CO}}\right)=1672.87 \mathrm{~cm}^{-1}$; HRMS (MALDI-TOF) Calcd for $\mathrm{C}_{20} \mathrm{H}_{17} \mathrm{O}\left[\mathrm{M}^{+}: 273.1279\right.$. Found: 273.1207

\section{2-acetylbenzo[c]phenanthrene(7)}

To a solution of the diarylethylene6 $(0.55 \mathrm{~g}, 2.03 \mathrm{mmol})$ in toluene $(1 \mathrm{~L})$ was added a catalytic amount of iodine. Irradiation was performed using a falling-film photoreactor and a high-pressure Hg-vapor lamp (500 W, Hanovia). The reaction was monitored by TLC. Following completion, the solvent was removed under reduced pressure and the crude residue was purified by a silica gel column chromatography with cyclohexane/EtOAc (98/02) as the eluent. 84\% yield, white solid; $R_{\mathrm{f}}=0.45 ; \mathrm{mp}=94-96{ }^{\circ} \mathrm{C} ;{ }^{1} \mathrm{H}$ NMR $\left(300 \mathrm{MHz}, \mathrm{CDCl}_{3}\right): \delta(\mathrm{ppm}): 2.81\left(\mathrm{~s}, 3 \mathrm{H}, \mathrm{CH}_{3}\right), 7.72\left(\mathrm{td}, J_{1}=9 \mathrm{~Hz}, J_{2}=3\right.$ $\mathrm{Hz}, 1 \mathrm{H}), 7.78\left(\mathrm{td}, J_{1}=9 \mathrm{~Hz}, J_{2}=3 \mathrm{~Hz}, 1 \mathrm{H}\right), 7.87(\mathrm{~d}, J=9 \mathrm{~Hz}, 1 \mathrm{H}), 7.91-7.99(\mathrm{~m}, 3 \mathrm{H}), 8.07(\mathrm{~d}, J=9 \mathrm{~Hz}, 2 \mathrm{H}), 8.19\left(\mathrm{dd}, J_{1}=\right.$ $\left.9 \mathrm{~Hz}, J_{2}=3 \mathrm{~Hz}, 1 \mathrm{H}, \mathrm{H}-3\right), 9.06(\mathrm{~d}, J=9 \mathrm{~Hz}, 1 \mathrm{H}, \mathrm{H}-12), 9.76(\mathrm{~s}, 1 \mathrm{H}, \mathrm{H}-1) ;{ }^{13} \mathbf{C} \mathbf{R M N}:\left(75 \mathrm{MHz}, \mathrm{CDCl}_{3}\right): \delta(\mathrm{ppm}): 26.45$ $\left(\mathrm{CH}_{3}\right), 123.86(\mathrm{CH}), 125.89(\mathrm{CH}), 126.19(\mathrm{CH}), 126.28(\mathrm{CH}), 126.40(\mathrm{CH}), 127.16(\mathrm{CH}), 127.64(\mathrm{CH}), 128.30(\mathrm{CH}), 128.38$ $(\mathrm{CH}) 129.06(\mathrm{CH}), 129.24(\mathrm{CH}), 129.48(\mathrm{C}), 130.77(2 \mathrm{C}), 133.22(\mathrm{C}), 133.92(2 \mathrm{C}), 135.50(\mathrm{C}), 197.89(\mathrm{CO}) ; \mathrm{IR}:\left(\mathrm{v}_{\mathrm{CO}}\right)=$ $1728.09 \mathrm{~cm}^{-1}$; HRMS (MALDI-TOF) Calcd for $\mathrm{C}_{20} \mathrm{H}_{15} \mathrm{O}[\mathrm{M}]^{+}: 271.1123$. Found: 271.2480.

\section{General procedure for the investigated amines}

A $50 \mathrm{~mL}$ round-bottom flask equipped with a magnetic stirring bar and a Dean-Stark apparatus was charged with $100 \mathrm{mg}$ of benzo[c]phenanthrene ketone 7 (3.7 mmol), (1.25 equiv.) of the appropriate primary amine, $9 \mathrm{mg}$ of zinc chloride $(10 \mathrm{~mol} \%)$ and $50 \mathrm{~mL}$ of toluene. The reaction mixture was refluxed for 8 hours (until collection of water stopped), then it was cooled and the solvent was removed under reduced pressure. The resulting imine was dissolved in $5 \mathrm{~mL}$ of methanol, stirred under nitrogen atmosphere and cooled to $0^{\circ} \mathrm{C}$, then sodium borohydride $(7.4 \mathrm{mmol})$ was added and the mixture was stirred at room temperature for 2 hours. $6 \mathrm{~mL}$ of $\mathrm{HCl}(6 \mathrm{M})$ was then added dropwise to the reaction mixture until hydrogen production ceased. The organic phase was then extracted with $\mathrm{CH}_{2} \mathrm{Cl}_{2}(3 \times 30 \mathrm{~mL})$, dried with anhydrous $\mathrm{Na}_{2} \mathrm{SO}_{4}$, then filtered and concentrated. Chromatographic separation was performed, on the obtained crude oil, with cyclohexane/EtOAc (98/02 up to 80/20) and afforded the chiral secondary amines.

\section{Spectroscopic data for $\mathrm{N}$-[1-(benzo[c]phenanthren-2-yl)ethyl]- $N$-phenylamine (10)}

$68 \%$ yield, yellow oil; $R_{\mathrm{f}}=0.45$ (cyclohexane/EtOAc: $\left.95 / 05\right) ;{ }^{1} \mathrm{H}$ NMR $\left(300 \mathrm{MHz}, \mathrm{CDCl}_{3}\right): \delta(\mathrm{ppm}): 1.66(\mathrm{~d}, J=9 \mathrm{~Hz}$, $\left.3 \mathrm{H},-\mathrm{CH}_{3}\right), 4.36(\mathrm{~s}, 1 \mathrm{H}, \mathrm{NH}), 4.86(\mathrm{q}, J=6 \mathrm{~Hz}, 1 \mathrm{H}), 6.67-6.79(\mathrm{~m}, 3 \mathrm{H}), 7.18-7.23(\mathrm{~m}, 2 \mathrm{H}), 7.40-7.48(\mathrm{~m}, 1 \mathrm{H}), 7.57-7.67(\mathrm{~m}$, $2 \mathrm{H}), 7.81(\mathrm{~d}, J=9 \mathrm{~Hz}, 1 \mathrm{H}), 7.82(\mathrm{~d}, J=9 \mathrm{~Hz}, 1 \mathrm{H}), 7.90(\mathrm{~d}, J=9 \mathrm{~Hz}, 2 \mathrm{H}), 8.02(\mathrm{t}, J=9 \mathrm{~Hz}, 2 \mathrm{H}, \mathrm{H}-10$ and H-11), $8.70(\mathrm{~d}, J$ $=9 \mathrm{~Hz}, 1 \mathrm{H}, \mathrm{H}-12), 9.09(\mathrm{~s}, 1 \mathrm{H}, \mathrm{H}-1) ;{ }^{13} \mathrm{C} \mathrm{RMN}\left(75 \mathrm{MHz}, \mathrm{CDCl}_{3}\right): \delta(\mathrm{ppm}): 24.54\left(\mathrm{CH}_{3}\right), 53.23(\mathrm{CH}), 113.35(2 \mathrm{CH}), 117.13$ $(\mathrm{CH}), 123.92(\mathrm{CH}), 124.08(\mathrm{CH}), 125.21(\mathrm{CH}), 125.72(\mathrm{CH}), 125.97(\mathrm{CH}), 126.22(\mathrm{CH}), 126.57(\mathrm{CH}), 126.88(\mathrm{C}), 126.95$ $(\mathrm{CH}), 127.36(\mathrm{CH}), 127.89(\mathrm{CH}), 128.12(\mathrm{C}), 128.42(\mathrm{CH}), 128.72(2 \mathrm{CH}), 129.82(\mathrm{C}), 129.93(\mathrm{C}), 130.68(\mathrm{C}), 132.21(\mathrm{C})$, $132.98(\mathrm{C}), 141.86(\mathrm{C})$; ESI-MS: $\mathrm{m} / \mathrm{z}=347[\mathrm{M}]^{+}$.

\section{Spectroscopic data fordiastereoisomer (13a)}

$72 \%$ yield, yellow oil; $R_{\mathrm{f}}=0.25$ (cyclohexane/EtOAc: 98/02); ${ }^{1} \mathbf{H}$ NMR $\left(300 \mathrm{MHz}, \mathrm{CDCl}_{3}\right): \delta(\mathrm{ppm}): 1.44(\mathrm{~d}, J=6 \mathrm{~Hz}$, $\left.3 \mathrm{H},-\mathrm{CH}_{3}\right), 1.46\left(\mathrm{~d}, J=6 \mathrm{~Hz}, 3 \mathrm{H}, \mathrm{CH}_{3}\right), 1.98(\mathrm{~s}, 1 \mathrm{H}, \mathrm{NH}), 3.83(\mathrm{q}, \mathrm{J}=6 \mathrm{~Hz}, 1 \mathrm{H}, \mathrm{CH}), 3.93(\mathrm{q}, J=6 \mathrm{~Hz}, 1 \mathrm{H}, \mathrm{CH}), 7.30-7.42$ $\left(\mathrm{m}, 5 \mathrm{H}, \mathrm{H}_{\text {benz }}\right), 7.62-7.69\left(\mathrm{~m}, 3 \mathrm{H}, \mathrm{H}-3\right.$ and $\left.2 \mathrm{H}_{\text {arom }}\right), 7.84(\mathrm{~d}, \mathrm{~J}=9 \mathrm{~Hz}, 1 \mathrm{H}, \mathrm{H}-10), 7.85\left(\mathrm{~d}, \mathrm{~J}=9 \mathrm{~Hz}, 1 \mathrm{H}, \mathrm{H}_{\text {arom }}\right), 7.92(\mathrm{~d}, J=9$ $\mathrm{Hz}, 1 \mathrm{H}, \mathrm{H}-11), 7.94(\mathrm{~d}, J=9 \mathrm{~Hz}, 1 \mathrm{H}, \mathrm{H}-4), 8.04\left(\mathrm{~d}, J=9 \mathrm{~Hz}, 2 \mathrm{H}, 2 \mathrm{H}_{\text {arom }}\right), 8.99(\mathrm{~s}, 1 \mathrm{H}, \mathrm{H}-1), 9.10$ (dd, $J_{1}=9 \mathrm{~Hz}, J_{2}=1.2$ $\mathrm{Hz}, 1 \mathrm{H}, \mathrm{H}-12) ;{ }^{13} \mathbf{C} \mathbf{R M N}\left(75 \mathrm{MHz}, \mathrm{CDCl}_{3}\right): \delta(\mathrm{ppm}): 25.12\left(\mathrm{CH}_{3}\right), 25.20\left(\mathrm{CH}_{3}\right), 55.51(\mathrm{CH}), 55.77(\mathrm{CH}), 124.65(\mathrm{CH})$, $125.73(\mathrm{CH}), 125.93\left(\mathrm{C}_{1}\right), 126.06\left(\mathrm{C}_{3}\right), 126.40(\mathrm{CH}), 126.75\left(2 \mathrm{CH}_{\text {benz }}\right), 126.87\left(\mathrm{CH}_{\text {benz }}\right), 126.92\left(\mathrm{C}_{10}\right), 127.29\left(\mathrm{C}_{4}\right), 127.40$ $\left(\mathrm{C}_{11}\right), 127.85\left(\mathrm{C}_{12}\right), 128.41(\mathrm{C}), 128.55\left(2 \mathrm{CH}_{\text {benz }}\right), 128.57(\mathrm{CH}), 128.90\left(\mathrm{C}_{9}\right), 130.45(\mathrm{C}), 130.51(\mathrm{C}), 131.28(\mathrm{C}), 132.90$ (C), 133.62 (C), 143.67 (C), 145.88 (C); HRMS (MALDI-TOF) Calcd for $\mathrm{C}_{28} \mathrm{H}_{26} \mathrm{~N}[\mathrm{M}]^{+}: 376.2065$. Found: 376.2068.

\section{Spectroscopic data for diastereoisomer (13b)}

$18 \%$ yield, yellow oil; $R_{\mathrm{f}}=0.23$ (cyclohexane/EtOAc: $\left.98 / 02\right) ;{ }^{1} \mathrm{H}$ NMR $\left(300 \mathrm{MHz}, \mathrm{CDCl}_{3}\right): \delta(\mathrm{ppm}): 1.45(\mathrm{~d}, J=6 \mathrm{~Hz}$ $\left.3 \mathrm{H},-\mathrm{CH}_{3}\right), 1.54\left(\mathrm{~d}, J=6 \mathrm{~Hz}, 3 \mathrm{H}, \mathrm{CH}_{3}\right), 2.08(\mathrm{~s}, 1 \mathrm{H}, \mathrm{NH}), 3.95(\mathrm{q}, J=6 \mathrm{~Hz}, 1 \mathrm{H}, \mathrm{CH}), 4.15(\mathrm{q}, J=6 \mathrm{~Hz}, 1 \mathrm{H}, \mathrm{CH}), 7.25-7.38$ ( $\left.\mathrm{m}, 5 \mathrm{H}, \mathrm{H}_{\text {benz }}\right), 7.60-7.63\left(\mathrm{~m}, 3 \mathrm{H}, \mathrm{H}-3\right.$ and $\left.2 \mathrm{H}_{\text {arom }}\right), 7.81(\mathrm{~d}, J=9 \mathrm{~Hz}, 1 \mathrm{H}, \mathrm{H}-10), 7.82\left(\mathrm{~d}, J=9 \mathrm{~Hz}, 1 \mathrm{H}, \mathrm{H}_{\text {arom }}\right), 7.88(\mathrm{~d}, J=9$ $\mathrm{Hz}, 1 \mathrm{H}, \mathrm{H}-11), 7.90(\mathrm{~d}, J=9 \mathrm{~Hz}, 1 \mathrm{H}, \mathrm{H}-4), 7.97-8.04\left(\mathrm{~m}, 2 \mathrm{H}, 2 \mathrm{H}_{\text {arom }}\right), 9.04(\mathrm{~s}, 1 \mathrm{H}, \mathrm{H}-1), 9.07(\mathrm{~d}, \mathrm{~J}=9 \mathrm{~Hz}, 1 \mathrm{H}, \mathrm{H}-12) ;{ }^{13} \mathrm{C}$ $\operatorname{RMN}\left(75 \mathrm{MHz}, \mathrm{CDCl}_{3}\right): \delta(\mathrm{ppm}): 22.65\left(\mathrm{CH}_{3}\right), 22.99\left(\mathrm{CH}_{3}\right), 54.75(\mathrm{CH}), 55.20(\mathrm{CH}), 124.30(\mathrm{CH}), 125.22\left(\mathrm{C}_{1}\right.$ and $\left.\mathrm{CH}\right)$, $125.56\left(\mathrm{C}_{3}\right), 125.93\left(\mathrm{C}_{10}\right), 126.15\left(\mathrm{CH}_{\text {benz }}\right), 126.35\left(\mathrm{CH}_{\text {benz }}\right), 126.69(\mathrm{CH}), 126.87\left(\mathrm{C}_{11}\right), 127.33\left(\mathrm{C}_{4}\right), 127.86(\mathrm{C}), 127.93$ $\left(\mathrm{C}_{12}\right), 128.02\left(2 \mathrm{CH}_{\text {arom }}\right), 128.25(\mathrm{CH}), 129.91(\mathrm{C}), 129.95(\mathrm{C}), 130.72(\mathrm{C}), 132.29(\mathrm{C}), 133.07(\mathrm{C}), 143.08(\mathrm{C}), 145.40(\mathrm{C})$.

\section{Conclusion}

In summary, we have developed a simple and efficient synthetic approach leading to 2-acetylbenzo[c]phenanthrene in $61 \%$ overall yield. The present resultmay be evidence for the potential of this class of frameworks inthe search and development of new chiral amines which could serve as ligands in asymmetric synthesis. In the other hand, the cytotoxic activity of the new benzo[c]phenanthrene derivatives has been evaluated against Hep-2cell line using (MTT) colorimetric assay and showed interesting results. 


\section{ACKNOWLEDGMENTS}

The authors are grateful to the DGRSRT (Direction Générale de la RechercheScientifiqueet de la RénovationTechnologique) of the Tunisian Ministry of Higher Education and Scientific Research.

\section{REFERENCES}

[1] Cheung J., Field L. D., Regalia F., Sternhell S.,A convenient synthesis of partially reduced benzo[c]phenanthrenes its ketals and ketones, Aust. J. Chem.48 (1995) 1707.

[2] Harvey R. G., Polycyclic Aromatic Hydrocarbons; Chemistry and Carcinogenicity Cambridge University Press: Cambridge, UK 1991 Chapter 3.

[3] Stevenson J. L., Von Haam E., Carcinogenicity of benz[a]anthracene and benzo[c]phenanthrene derivatives, Am. Ind. Hyg. Assoc. J.26 (1965) 475.

[4] AlouiF.,El AbedR.,MarinettiA.,Ben Hassine B.,Synthesis and characterization of new hexahelicene derivatives, Tetrahedron Lett.48 (2007) 2017.

[5] AlouiF.,MoussaS.,Ben Hassine B.,Synthesis and characterization of a new hexacyclichelicene, Tetrahedron Lett.53 (2012) 3216.

[6] Lefebvre Q., Jentsch M., Rueping M.,Continuous flow photocyclization of stilbenes-scalable synthesis of functionalized phenanthrenes and helicenes, Beilstein J. Org. Chem.9 (2013) 1883.

[7] Karikomi M., Yamada M., Ogawa Y., Houjou H., Seki K., Hiratani K., Haga K., Uyehara T.,Novel synthesis of a unique helical quinone derivative by coupling reaction of 2-hydroxybenzo[c]phenanthrene, Tetrahedron Lett.46 (2005) 5867.

[8] Pataki J., DiRaddo P., Harvey R. G.,An efficient synthesis of the highly tumorigenic anti-diol epoxide derivative of benzo[c]phenanthrene,J. Org. Chem.54 (1989) 840.

[9] Thirunarayanan G.,Vanangamudi G.,Synthesis, spectral studies, antimicrobial and insect antifeedant activities of some substituted styryl 4'-fluorophenyl ketones, Arabian Journal of Chemistry7 (2014) 1055.

[10] Marquise N., Chevallier F., Nassar E., Frédérich M., Ledoux A., Halauko Y. S., Ivashkevich O. A., Matulis V. E., Roisnel T.,Dorcet V., Mongin F.,Substituted Azafluorenones: Access from dihalogenodiaryl ketones by Palladiumcatalyzed auto-tandem processes and evaluation of their antibacterial, antifungal, antimalarial and antiproliferative activities, Tetrahedron72 (2016) 825.

[11] Karpaviciene I., Valiuliene G., Raskevicius V., Lebedyte I., Brukstus A., Kairys V., Navakauskiene R., Cikotiene I.,Synthesis and antiproliferative activity of $\alpha$-branched $\alpha, \beta$-unsaturated ketones in human hematological and solid cancer cell lines, European Journal of Medicinal Chemistry98 (2015) 30.

[12] Ning X., Guo Y., Ma X., Zhu R., Tian C., Wang X., Mac Z., Zhang Z., Liu J.,Synthesis and neuroprotective effect of E3,4-dihydroxy styrylaralkyl ketones derivatives against oxidative stress and inflammation,Bioorganic \& Medicinal Chemistry Letters23 (2013) 3700.

[13] Ben Hassine B., Gorsane M., Pecher J., Martin R. H.,Diastereoselective $\mathrm{NaBH}_{4}$ reductions of (dl) $\alpha$-keto esters, Bull. SOC. Chim. Belg.94 (1985) 597.

[14] Schiff H.,A new range of organic bases,Ann. Chem.131 (1864) 118.

[15] Moffett R. B., Rabjohn N.,Editor, Organic Synthesis; John Wiley \&Sons, Inc., New York4, 1963, 605.

[16] Johansson A., Methods for the asymmetric preparation of amines, Contemporary Organic Synthesis2 (1995) 393.

[17] Duthaler R. O.,Recent developments in the stereoselective synthesis of $\alpha$-aminoacids, Tetrahedron50 (1994) 1539.

[18] Juaristi E.,Enantioselective synthesis of beta-amino acids. Wiley-VCH Publishers, New York, 1997, 45.

[19] Clifton J. E., Collins I., Hallett P., Hartley D., Lunts L. H. C., Wicks P. D.,Arylethanolamines derived from salicylamide with .alpha.- and .beta.-adrenoceptor blocking activities. Preparation of labetalol, its enantiomers and related salicylamides, J. Med. Chem.25 (1982) 670.

[20] Betti M., $\beta$-naphtholphenylaminomethane,Org. Synth.1 (1941) 381.

[21] Cardellicchio C., Ciccarella G., Naso F., Schingaro E., Scordari F., The Betti base: absolute configuration and routes to a family of related chiral nonracemic bases, Tetrahedron: Asymmetry9 (1998) 3667.

[22] Semakin A. N., Agababyan D. P., Kim S., Lee S., Yu Sukhorukov A., Fedina K. G., Oh J., loffe S. L.,Oximinoalkylamines as ligands for Cu-assisted azide-acetylene cycloaddition, Tetrahedron Lett.56 (2015) 6335.

[23] KlugeT., Bette M., Vetter C., Schmidt J., Steinborn D.,Synthesis and characterization of diacetyl platinum(II) complexes with two primary and secondary amine ligands, Journal of Organometallic Chemistry715 (2012) 93.

[24] Bálint E., Tripolszky A., Jablonkai E., Karaghiosoff K., Czugler M., Mucsi Z., Kollár L., Pongrácz P., Keglevich G.,Synthesis and use of $\alpha$-aminophosphine oxides and $N, N$-bis(phosphinoylmethyl)amines-A study on the related ring platinum complexes, Journal of Organometallic Chemistry801 (2016) 111.

[25] Kumar V., Upadhyay N., Manhas A.,Designing, syntheses, characterization, computational study and biological activities of silver-phenothiazine metal complex, Journal of Molecular Structure1099(2015) 135.

[26] Backvall J. E., Bjorkman E. E., Bystrom S. E.,Palladium-promoted asymetricoxyamination of alkenes application to the synthesis of optically active aryloxypropanolamines, Tetrahedron Lett.23 (1982) 943.

[27] Zhang G., Ji X., Yu H., Yang L., Jiao P., Huang H.,Palladium-catalyzed hydroaminocarbonylation of alkenes with amines promoted by weak acid, Tetrahedron Lett.57 (2016) 383.

[28] Cottineau F., Maigrot N., Mazaleyrat J. P.,Reductive cleavage of axially disymmetric tertiary amines and quaternary ammonium salts by lithium aluminium hydride. Synthesis of new 1,1'-binaphthyl substituted amines, Tetrahedron Lett.26 (1985) 421.

[29] Huang P. Q., Wang Y., Xiao K. J., Huang Y. H.,A general method for the direct transformation of common tertiary amides into ketones and amines by addition of Grignard reagents, Tetrahedron71 (2015) 4248. 


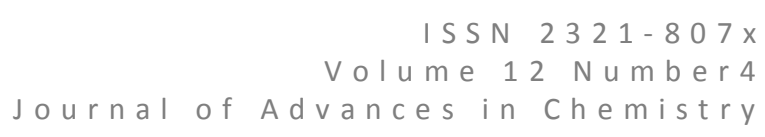

[30] Wu B., Gao X., Chen M. W., Zhou Y. G.,Direct amination of 2-(1-tosylalkyl)phenols with aqueous ammonia: a metalfree synthesis of primary amines, Tetrahedron Lett.56 (2015) 1135.

[31] Liew S. K., He Z., St Denis J. D., Yudin A. K.,Stereocontrolled synthesis of 1,2- and 1,3-diamine building blocks from aziridine aldehyde dimmers, J. Org. Chem.78 (2013) 11637.

[32] Gomez-Bengoa E., Jimenez J., Lapuerta I., Mielgo A., Oiarbide M., Otazo I., Velilla I., Vera S., Palomo C., Combined a, a-dialkylprolinol ether/Brønsted acid promotes Mannich reactions of aldehydes with unactivated imines. An entry to anti-configured propargylic amino alcohols, Chem. Sci.3 (2012) 2949.

[33] Izumiseki A., Yoshida K., Yanagisawa A.,Catalytic asymmetric three-component mannich-type reaction of alkenyl trichloroacetates, Org. Lett.11 (2009) 5310.

[34] Parmar D., Sugiono E., Raja S., Rueping M.,Complete field guide to asymmetric BINOL-phosphate derived Brønsted Acid and metal catalysis: History and classification by mode of activation; Brønsted acidity, hydrogen bonding, ion pairing, and metal phosphates, Chem. Rev.114 (2014) 9047.

[35] Wang D. -S., Chen Q. -A., Li W., Yu C. -B., Zhou Y. -G., Zhang X.,Pd-Catalyzed asymmetric hydrogenation of unprotected indoles activated by Brønsted acids, J. Am. Chem. Soc.132 (2010) 8909.

[36] Hou G., Gosselin F., Li W., McWilliams J. C., Sun Y., Weisel M., O'Shea P. D., Chen C. -Y., Davies I. W., Zhang X.,Enantioselective Hydrogenation of N-H Imines, J. Am. Chem. Soc.131 (2009) 9882.

[37] Kuehne M. E., The applications of enamines to a new synthesis of b-ketonitriles, J. Am. Chem. Soc.81 (1959) 5400.

[38] Taguchi K., Westheimer F. H.,Catalysis by molecular sieves in the preparation of ketimines and enamines,J. Org. Chem.36 (1971) 1570.

[39] Jaworska M., Łaczkowski K. Z., Wełniak M., Welke M., Wojtczak A.,Imines derived from (1S, 2R)-norephedrine as catalysts in the enantioselective addition of diethylzinc to aldehydes, Applied Catalysis A: Generaß357 (2009) 150.

[40] Billman J. H., Tai K. M. J.,Reduction of Schiff bases. II. Benzhydrylamines and structurally related compounds,J. Org. Chem.23 (1958) 535.

[41] Bolton R., Dank T. N., PaulJ. M.,Preparation and reduction of some camphor imines, Tetrahedron Lett.35 (1994) 3411.

[42] Emerson W. S.,Organic Reactions,Wiley, New York 4, 1948, 174.

[43] Hutchins R. O.,Natale N.,Cyanoborohydride. Utility and applications in organic synthesis. A review,Org. Prep. Proced. Int.11 (1979) 201.

[44] Whitesell J. K., in Comprehensive Organic Synthesis, Trost B. M., Fleming, I.Ed. Pergamon Press, Oxford 6, 1991, 724and 825.

[45] (a) GribbleG. W., in Reductions in Organic Synthesis, ACS Symposium Series641, Abdel-Majid, A. F. Ed. American Chemical Society, Washington, DC, 1996, 167; (b) Abdel-Majid, A. F. ibid, 201.

[46] Abirami M., Gopiesh Khanna V., Kannabiran K.,Antibacterial activity of marine Streptomyces SP. isolated from Andaman \& Nicobar Islands, Int J Pharm. Bio. Sci.4 (2013) 280.

[47] Chen J. J., Hung H. C., Sung P. J., Chen I. S., Kuo W. L.,Aporphine alkaloids and cytotoxic lignans from the roots of Illigeraluzonensis, Phytochemistry72 (2011) 523.

[48] Yazdiniapour Z., Ghanadian M., Zolfaghari B., Lanzotti V.,6(17)-Epoxylathyranediterpenes from Euphorbia sogdiana Popov with cytotoxic activity, Fitoterapia108 (2016) 87.

[49] Hu J., Song Y., Mao X., Wang Z. J., Zhao Q. J.,Limonoids isolated from Toonasinensis and their radical scavenging, anti-inflammatory and cytotoxic activities, Journal of Functional Foods20 (2016) 1.

[50] Huang L. H., Li Y., Xu H. D., Zheng Y. F.,Liu H. M.,Synthesis and biological evaluation of novel C6-cyclo secondary amine substituted purine steroid-nucleosides analogues, Steroids85 (2014) 13.

[51] Akbaş H.,Okumuş A.,Kılıç Z.,Hökelek T.,Süzen Y.,Koç L. Y.,Açık L.,Çelik Z. B.,Phosphorus-nitrogencompounds part 27.Syntheses,structuralcharacterizations, antimicrobial and cytotoxic activities, and DNA interactions of new phosphazenes bearing secondary amino and pendant (4-fluorobenzyl)spiro groups, European Journal of Medicinal Chemistry70 (2013) 294.

\section{Figures captions}

Figure 1- Representative examples of benzo[c]phenanthrene derivatives.

Scheme 1- Synthetic procedure of the tetracyclic ring system 7.

Figure2- Normalized UV/vis absorption spectra of diarylethene6 and the tetracyclic system 7 in dilute dichloromethane solutions $\left(1.5 \times 10^{-6} \mathrm{M}\right)$.

Figure 3- Normalized emission of compounds 6 and 7 inthin solid film.

Figure 4- a) Gaussian fits for diarylethene6; b) Gaussian fits for 2-acetylbenzo[c]-phenanthrene7.

Scheme 2-Synthesis of the new racemic secondary amine $\mathbf{1 0 .}$

Scheme 3-Synthetic pathway for the synthesis of the optically active amines 13a,b.

Figure 3-Cytotoxic activity of benzo[c]phenanthrene derivatives against Hep-2 cell line

(Values were expressed as means \pm standard deviation of three experiments). 